\title{
Article \\ Cytotoxicity of Quillaja saponaria Saponins towards Lung Cells Is Higher for Cholesterol-Rich Cells
}

\author{
Natalia Kozińska, Katarzyna Tokarska, Michał Chudy (D) and Kamil Wojciechowski *(D) \\ Faculty of Chemistry, Warsaw University of Technology, Noakowskiego 3, 00-664 Warsaw, Poland; \\ natalie.kozinska@gmail.com (N.K.); ktokarska@ch.pw.edu.pl (K.T.); chudziak@ch.pw.edu.pl (M.C.) \\ * Correspondence: kamil.wojciechowski@ch.pw.edu.pl
}

\begin{abstract}
The purpose of the study was to compare cytotoxicity of two Quillaja saponaria bark saponin (QBS) mixtures against two lung cell lines: normal MRC-5 fibroblast cell line and tumor A-549 epithelial cells of lungs' alveoli. The study, performed both at a macro-scale and in a dedicated microfluidic device, showed that QBS was more toxic to the cell line more abundant in cholesterol (MRC-5). The QBS mixture with higher saponin fraction was found to be more cytotoxic towards both cell lines. The results may help to better understand the cytotoxicity of saponin-rich herbal medicines towards normal and tumor cells depending on their cholesterol content.
\end{abstract}

Keywords: MRC-5; A549; cytotoxicity; saponins; microfluidics

Citation: Kozińska, N.; Tokarska, K.; Chudy, M.; Wojciechowski, K. Cytotoxicity of Quillaja saponaria Saponins towards Lung Cells Is Higher for Cholesterol-Rich Cells. Biophysica 2021, 1, 126-136. https://doi.org/10.3390/ biophysica1020010

Academic Editor: Matthias Buck

Received: 25 January 2021

Accepted: 1 April 2021

Published: 6 April 2021

Publisher's Note: MDPI stays neutral with regard to jurisdictional claims in published maps and institutional affiliations.

Copyright: (c) 2021 by the authors. Licensee MDPI, Basel, Switzerland. This article is an open access article distributed under the terms and conditions of the Creative Commons Attribution (CC BY) license (https:/ / creativecommons.org/licenses/by/ $4.0 /)$.

\section{Introduction}

Saponins are secondary metabolites found mostly in plants [1]. Their biological role has not been fully elucidated yet, but is most likely related to the plant organisms' defense against predators [2]. Certain saponins are toxic in their native form, while others become biologically active only upon chemical transformation. For example, the normally non-toxic saponins avenacosides A and B, stored in healthy leaves of oat, can become hydrolyzed by the plant's enzyme avenacosidase to release antifungal membranolytic products in response to a fungal infection [3]. Saponins are by no means the sole biologically active molecules produced by plants, yet the cooperative activity of different biomolecules is often ignored. One known example of such activity is the saponin-saporin cooperativity. Saporins are ribosome-inactivating protein (RIP) toxins that require assistance of saponins to successfully enter the cytosolic compartment of the attacked cell $[4,5]$.

Many saponins, including Quillaja saponaria bark saponin (QBS), display pronounced amphiphilic character [6-8] and have been traditionally used mostly as foaming and cleaning agents; hence the name "saponins", which derives its origin from a Latin word for soap-"sapo" [9,10]. Purifying saponin-rich plant extracts such as QBS, containing dozens of saponins and several other components (polyphenols, tannins, sugars, calcium oxalate, etc.) [11] is still a complicated and time-consuming task [10,12]. Hence, in most cases, mixtures of saponins are used, except for special applications, such as an adjuvant for vaccines QS-21 [13]. The hydrophobic parts of saponin molecules present in QBS comprise several triterpenoid aglycones, including quillaic acid (Figure 1). Their hydrophilic sugar chains (glycones) consist of typically 2-5 frequently branched sugar units attached to the C-3 and C-28 carbon atoms of the aglycone. The exact composition of a given QBS product depends on a number of factors, including the botanical conditions and extraction procedure (the use of highly alkaline or acidic conditions, temperature, etc.), but also on the sample history (e.g., storage conditions) [13-16]. 


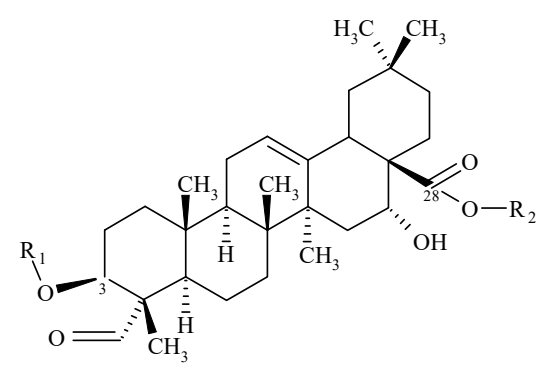

Figure 1. General structure of Quillaja bark saponins (QBS); R1 and R2 are different sugar groups.

Thanks to their surface activity and taste-modifying properties (sweet or bitter taste), often combined with high biological activity, saponins find numerous applications in the food, cosmetic, and pharmaceutical industries. For pharmaceutical applications, the saponin-cholesterol interaction, described for the first time more than a century ago [17,18], is especially important [19-27]. For many years, precipitation of cholesterol by a steroid saponin, digitonin, was even a basis of quantitative analysis of cholesterol in blood [28]. It should be stressed, however, that some saponins are capable of penetrating even the lipid bilayers devoid of cholesterol [29]. Thus, different modes of interaction of saponins with biological membranes are possible; some authors claim that saponins may primarily act on living cells via receptor-based specific interactions [30]. With our increasing understanding of the membrane activity of saponins, more and more studies are being devoted to their cytotoxic and anti-tumor activities. Numerous saponins showed promising cytotoxicity profiles suggesting potential applications in cancer treatments [31-38]. Despite the potent adjuvant activity (especially for some of its purified fractions) [39], QBS mixtures of different origins show generally low cytotoxicity. For example, a 90\% viability was observed for HER14 and NIH-3T3 fibroblast lines incubated with $1.5 \mu \mathrm{g} / \mathrm{mL}$ QBS solution [40]. The half maximal inhibitory concentration $\left(\mathrm{IC}_{50}\right)$ of QBS as high as $1000 \mu \mathrm{g} / \mathrm{mL}$ was observed for L929, BS-C-1, Vero, and CEMx174 cell lines [41]. Similar results were obtained for L929 and MA-104 murine fibroblasts lines [42]. On the other hand, in some instances, QBS was reported as being rather toxic to human and murine cells. For example, $\mathrm{IC}_{50}$ as low as $25 \mu \mathrm{g} / \mathrm{mL}$ was found for the murine CHO-K1 line [43], while for the human MRC-5 and murine J774 cell lines, even lower values were reported: $\mathrm{IC}_{50}=3 \mu \mathrm{g} / \mathrm{mL}$ and $\mathrm{IC}_{50}=0.3 \mu \mathrm{g} / \mathrm{mL}$, respectively [44].

The microfluidic approach offers numerous advantages for testing cytotoxicity [45]. It has shown a great promise in cancer research [46], point of care diagnostics [47], and DNA analysis [48] thanks to a rapid sample processing and low reagent consumption [49]. Other benefits of the microfluidic approach in biology come from a comparable scale of the device microstructure and of the cells. Furthermore, flow conditions, high surface area to volume ratio, fast diffusive heat, and mass transfer enable the process to more closely mimic the in vivo cell-cell or cell-extracellular matrix signals [50-52]. Despite the high potential for high-throughput screening, the microfluidic approach is rarely employed in cytotoxicity studies of saponins. To the best of our knowledge, only one study has thus far been devoted to the analysis of saponin cytotoxicity using a microfluidic setup [53].

In this contribution, we used a macroscopic cytotoxicity test (MTT) and a dedicated microfluidic setup (with dead cells stained with propidium iodide and the living ones with calcein AM) to compare cytotoxicity of two commercially available QBS mixtures ("Sigma" from Sigma-Aldrich and "SuperSap" from Desert King Int). In our previous report, the effect of both mixtures on model lipid monolayers was compared, pointing to significant differences resulting from the differences in saponin profiles and total saponin content [16]. The question that we want to answer in this contribution is to what extent the total amount of cholesterol in two lung cell lines and the saponin profile of two QBS mixtures affect the cytotoxic activity. 


\section{Materials and Methods}

\subsection{Chemicals}

Two commercially available Quillaja bark saponin mixtures (QBS) were used: Saponin (Sigma-Aldrich, 84510) and Super Sap (Desert King Int). They will be referred hereafter as "Sigma" and "SuperSap", respectively. Their saponin profiles were acquired using a reverse phase high performance liquid chromatography (RP-HPLC), as described in [16]. The chromatograms and the relative peak areas of the identified individual saponin for both mixtures are shown in Figure S1 (Supplementary Data). Trypsin (Sigma: T4799), phosphate-buffered saline (Sigma: P5493), Eagle's minimum essential medium (Sigma: M4655), and 70\% ethyl alcohol (POCH Poland) were used for cell culturing. Propidium iodide (Life Science: P4170), Calcein AM (Fluka: 17783), and Trypan Blue (Invitrogen: T10282) were used for cell staining. MTT assay consisted of a MTT Cell Proliferation Assay Kit (Vybrant: V-13154) and dimethyl sulfoxide (Sigma: D4540). Silicone elastomer curing agent and a polydimethylsiloxane(PDMS) silicone elastomer (Sylgard 184, DOW Corning), A1518 Developer (MicroChemicals GmbH), Photoresist S1818 (MicroChemicals), Capillary film, and Pro Cap 50 (Chromaline) were used for the microfluidic setup. Other chemicalshydrofluoric acid, ammonium fluoride, acetone, methanol, and isopropanol-were of analytical purity (p.a.) and were purchased from POCh Poland.

\subsection{Cell Lines}

Human cell line A-549-lung cancer epithelial cells (ATCC: CCL-185) and human cell line MRC-5 (ATCC: CCL-171) were used as lung cancer and normal cells, respectively.

\subsection{Cholesterol Content}

The whole-cell cholesterol content in dead cells from A-549 and MRC-5 lines was determined spectrophotometrically and fluorimetrically using a MAK043 kit from Sigma Aldrich. Cholesterol from the dead cells was extracted with a 7:11:0.1 mixture of chloroform, isopropanol, and Triton X-100 under sonication for $20 \mathrm{~min}$. The extract was centrifuged for $20 \mathrm{~min}$ at $4500 \mathrm{rpm}$ and dried using dry air and by storing in a desiccator under vacuum for $30 \mathrm{~min}$. The lipids were then suspended in a buffer and placed in a 96-well plate for quantitative analysis following the instructions of the MAK043 kit.

\subsection{Microfluidic Setup}

To fabricate microcavities for cell culture, we coated clean sodium glass slides (75 $\times 25 \times 1 \mathrm{~mm}$ ) under clean-room conditions with a thin layer of a photoresist using spin coating technique (1 min, $2000 \mathrm{rpm})$. They were subsequently irradiated with UV light for 3 min with the applied mask and washed with the developer and Milli-Q water, dried with nitrogen, and digested for 25 min with a mixture of $\mathrm{NH}_{4} \mathrm{~F}$ and $\mathrm{HF}$ (6:1). The PDMS part was fabricated with soft lithography method. First, a capillary film was placed on the sodium glass plates $(75 \times 25 \times 1 \mathrm{~mm})$ using a double-sided adhesive tape. The plates were then irradiated with UV light for 3 min through the mask with the concentration gradient generator pattern [54]. This stamp with a mapped design was covered with the liquid mixture of the prepolymer and cross-linking agent and heated $\left(70{ }^{\circ} \mathrm{C}, 2 \mathrm{~h}\right)$ until curing. In order to equip the PDMS layer with the inlets and outlet, we cooled the polymer with a liquid nitrogen prior to drilling the holes $(1.3 \mathrm{~mm})$. The PDMS part was finally bonded with the glass part in order to obtain the finished microfluidic system chip (Figure 2). 


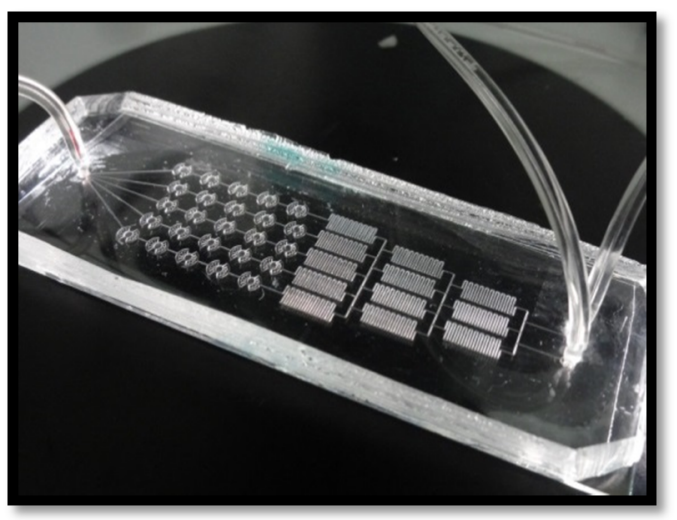

Figure 2. PDMS/glass microfluidic cell culture system for cytotoxicity tests of saponins.

\subsection{Cytotoxicity Measurement in the Micro Scale}

A pure culture medium and the "Sigma" or "SuperSap" QBS solution of $200 \mu \mathrm{g} / \mathrm{mL}$ concentration were introduced simultaneously into the chip at the rate of $1.5 \mathrm{~mL} / \mathrm{min}$ during $30 \mathrm{~min}$ with a peristaltic pump. The concentration gradient generator (as described in more detail in [54]) was employed to fill 5 lines of chambers with the solutions of 5 different QBS concentrations (200, 150, 100, 50, $0 \mu \mathrm{g} / \mathrm{mL}$ ). The cell viability was determined with a differential staining method. For this purpose, a mixture of propidium iodide (red color fluorescence, staining dead cells) and calcein AM (green color fluorescence, staining live cells) was introduced into the chip at the rate of $1.5 \mu \mathrm{L} / \mathrm{min}$ for $10 \mathrm{~min}$. Fluorescence images of each chamber were taken using an inverted fluorescent microscope (Olympus IX71).

\subsection{Cytotoxicity Measurement in the Macro Scale Using MTT Test}

The $200 \mu \mathrm{g} / \mathrm{mL}$ QBS solutions ("Sigma" or "SuperSap"), prepared as above, were diluted with pure culture medium in order to achieve the concentrations of 200, 150, 100, and $50 \mu \mathrm{g} / \mathrm{mL}$. The cell line passaging was performed on a sterile 96-well plate in the amount sufficient to obtain the cell density of $10^{5}$ cells per well and incubated for $24 \mathrm{~h}$ in $37^{\circ} \mathrm{C}$ until the cells adhered to the plate surface. Next, the medium from above the cells was removed and the respective QBS solutions were added ( $200 \mu \mathrm{L}$ per well). The plates were then incubated for $24 \mathrm{~h}$ at $37^{\circ} \mathrm{C}$. The test was performed according to the instructions of the Vybrant MTT Cell Proliferation Assay Kit. The medium from above the cells was replaced with the MTT reagent (60 $\mu \mathrm{L}$ per well), followed by incubation at $37^{\circ} \mathrm{C}$ until the conversion of MTT to formazan and consequent precipitation of the purple formazan crystals from the yellow MTT solution. After around $4 \mathrm{~h}$, the solution was carefully removed from above of the cells and $200 \mu \mathrm{L}$ of DMSO was added to each well to dissolve the formazan crystals. After $10 \mathrm{~min}$ of incubation at $37^{\circ} \mathrm{C}$, the absorbance at $\lambda=570 \mathrm{~nm}$ was measured on a previously calibrated multiwell plate reader (BIOTEK, Cytation 3).

\section{Results}

Saponins are known for their high affinity to membrane lipids, especially to sterols [14, $16,22,23,25,29,55,56]$. Consequently, numerous postulated mechanisms of membranolytic activity of saponins assume that the primary site of saponin attack is cholesterol [57-61]. To support this hypothesis, in the present study, we compared the effect of Quillaja saponins on cell lines differing in total cholesterol content. For this purpose, we chose two lung cell lines. A-549 is a lung cancer cell line, first developed by J. Giard et al. in 1972 from the explanted tumor of a 58-year-old Caucasian male. A-549 cells are basal epithelial cells of lungs' alveolis. The cells are adherent in in vitro environment, forming a monolayer [62]. The second cell line, MRC-5, are fibroblasts derived from normal lung tissue of a 14-week- 
old Caucasian male in 1966. In in vitro environment, the adherent cells of MRC-5 line also form a monolayer.

In the first step, the total cholesterol content in the cell lysates of A-549 and MRC-5 was determined using the spectrophotometric and fluorimetric assays. The two methods provided comparable results: $0.070 \pm 0.001 \mu \mathrm{g} / \mathrm{mL}$ and $0.101 \pm 0.007 \mu \mathrm{g} / \mathrm{mL}$, respectively, for MRC-5, and $0.030 \pm 0.001 \mu \mathrm{g} / \mathrm{mL}$ and $0.047 \pm 0.016 \mu \mathrm{g} / \mathrm{mL}$ for A-549, respectively. Interestingly, despite some discrepancy between the two methods, the ratio between the determined cholesterol content in MRC-5 and A-549 lysates was very close: 2.3 (for the spectrophotometric) and 2.2 (for the fluorimetric). Thus, for the purpose of this study, the normal lung fibroblast cells (MRC-5) were used as a model high-cholesterol cell line, while their tumor counterparts (A-549) were used as a low-cholesterol cell lilne. All subsequent experiments were performed in parallel for two commercially available QBS mixtures in order to enable discussion of possible effects of the differences in their composition. The mixtures are the same as those used in our previous study on the effect of QBS on model lipid monolayers and on the red blood cells: "Sigma" and "SuperSap" (see experimental section for more details).

The cytotoxicity was first assessed in a macro-scale using the cell metabolic activity test (MTT), as described in the experimental section. The results comparing the cytotoxic effect of both saponin mixtures on A-549 and MRC- 5 cell lines obtained from the MTT test are shown in Figure 3. Significant differences in general toxicity between the two extracts can be easily noticed. In the case of "SuperSap", already at the lowest tested concentration $(50 \mu \mathrm{g} / \mathrm{mL})$, only $20 \%$ of the cells survived, and thus the half maximal inhibitory concentration, $\mathrm{IC}_{50}$, for both lines was below $50 \mu \mathrm{g} / \mathrm{mL}$. The "Sigma" QBS was clearly less toxic, especially towards the cancer cells (A-549), for which a significant reduction of the cell viability could be noticed only at the highest concentration $(200 \mu \mathrm{g} / \mathrm{mL})$. Consequently, for the normal cell line, $\mathrm{IC}_{50}$ of "Sigma" could be estimated at around $50 \mu \mathrm{g} / \mathrm{mL}$, and for the cancerous cell line, at around $200 \mu \mathrm{g} / \mathrm{mL}$.

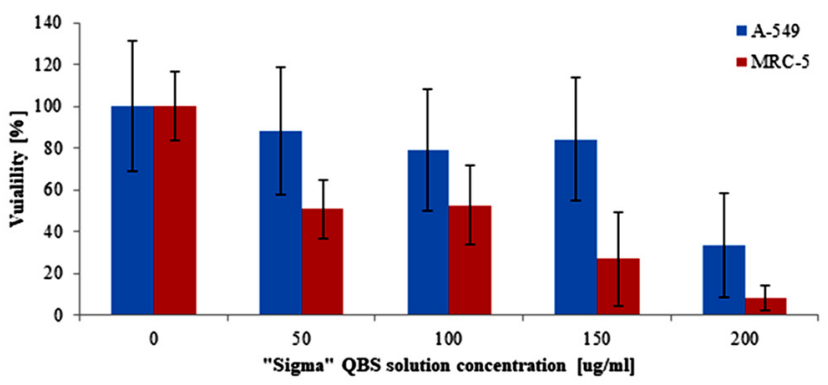

(a)

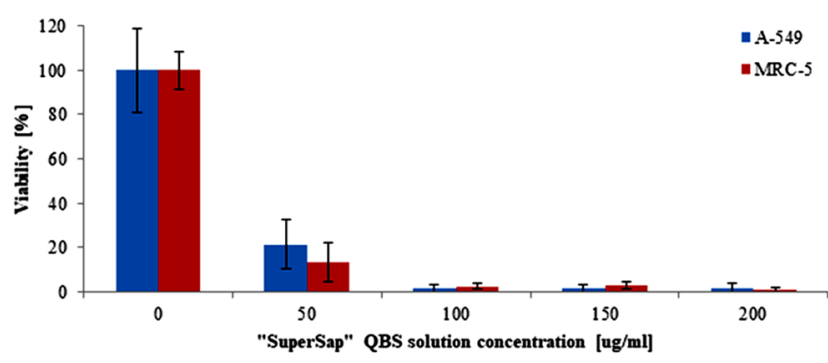

(b)

Figure 3. Viability of A-549 and MRC-5 cells (MTT test) after $24 \mathrm{~h}$ of incubation with (a) "Sigma" and (b) "SuperSap" Quillaja saponaria bark saponin (QBS) solutions on a macro scale. We assumed $100 \%$ cell viability for samples not treated with QBS solutions. Error bars were calculated from 18 measurements for three independent experiments.

In the next step, the cell viability was tested using a microfluidic setup. The setup allows for observation of the cell viability under a fluorescence microscope thanks to differential staining of alive (green) and dead cells (red). In line with the previously described results of the macroscopic MTT test, the representative microphotographs for $0,50,100$, and $200 \mu \mathrm{g} / \mathrm{mL}$ collected in Figure 4 point to important differences between the responses of both cell lines to QBS. The effect of "SuperSap" is evident at lower concentrations than for "Sigma". The viability results obtained from the analysis of the microphotographs of at least three independent microfluidic chips are collected in Figure 5. For both "SuperSap" and "Sigma" QBS, a dose-dependent cytotoxicity was observed. In both cases, QBS solutions were also more toxic towards the MRC-5 normal cells, with "SuperSap" being generally a stronger cytotoxic agent. For this mixture, the MRC-5 viability 
was about $20 \%$ at merely $50 \mu \mathrm{g} / \mathrm{mL}$, while above the concentration of $100 \mu \mathrm{g} / \mathrm{mL}$ both normal and cancer cells were already dead. For "Sigma", the full toxicity towards both cell lines was observed only at the highest tested concentration $(200 \mu \mathrm{g} / \mathrm{mL})$. Below this dose, the A549 viability remained at a quite high level above $60 \%$.

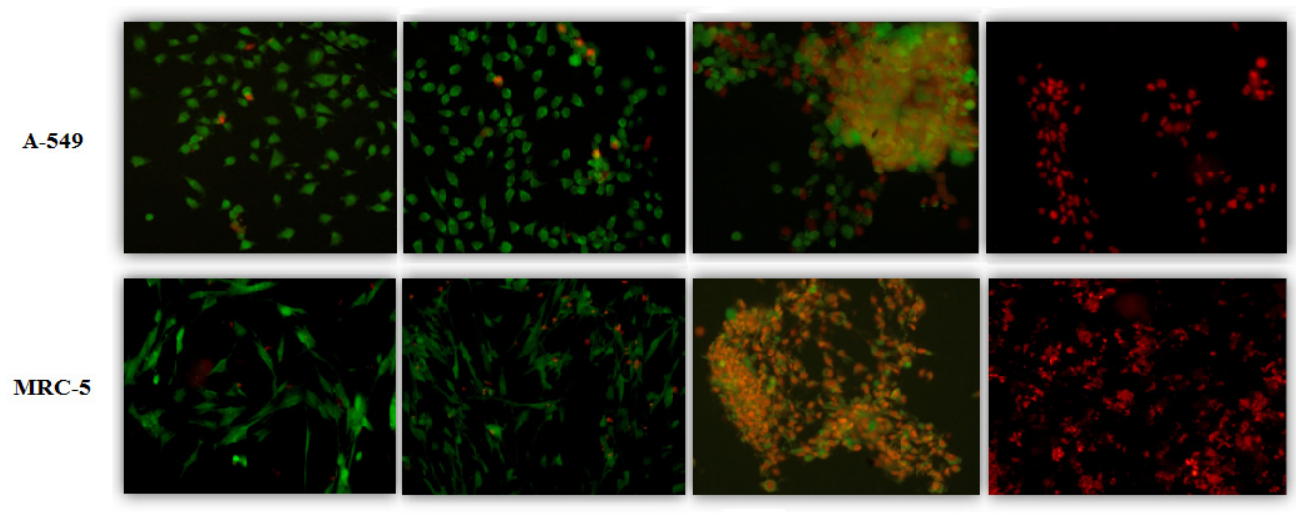

(a)

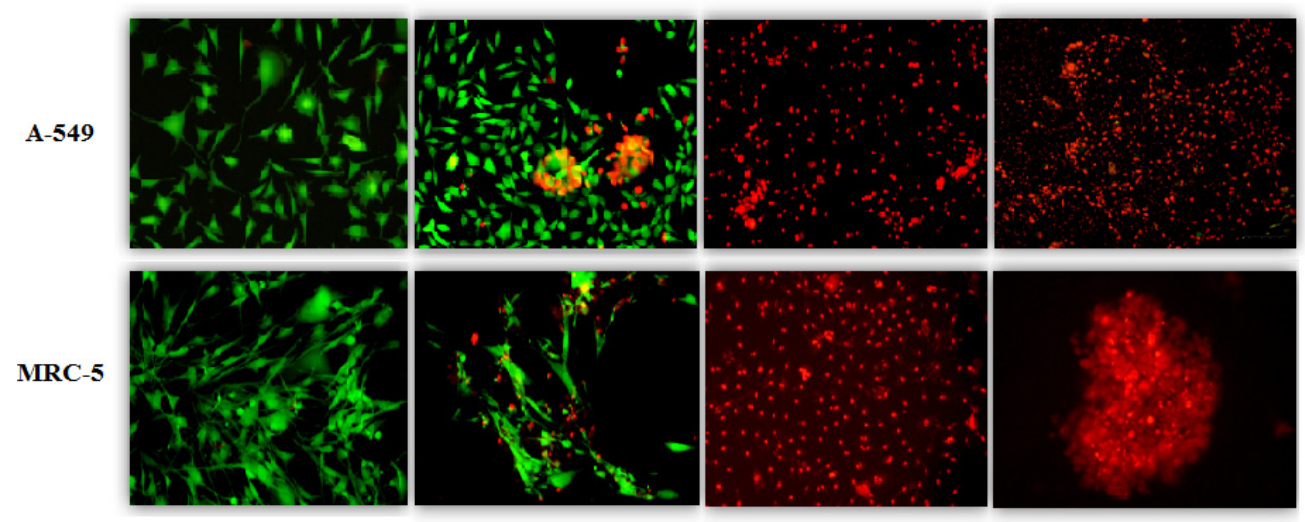

(b)

Figure 4. Photographs of A-549 and MRC-5 cell cultures after $24 \mathrm{~h}$ of incubation with "Sigma" and "SuperSap" QBS solutions (10× magnification). The top two rows (a) present the cells incubated with "Sigma" solution, and the bottom two (b) are these incubated with "SuperSap "QBS solution. The concentrations of saponin solutions in both cases were (from left) 0, 50, 100, and $200 \mu \mathrm{g} / \mathrm{mL}$, respectively.

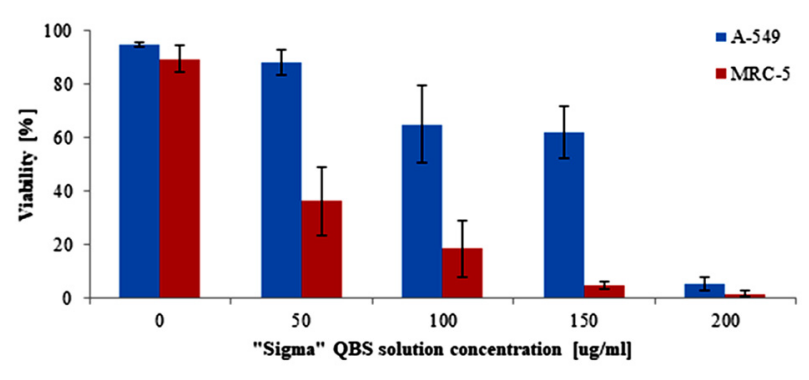

(a)

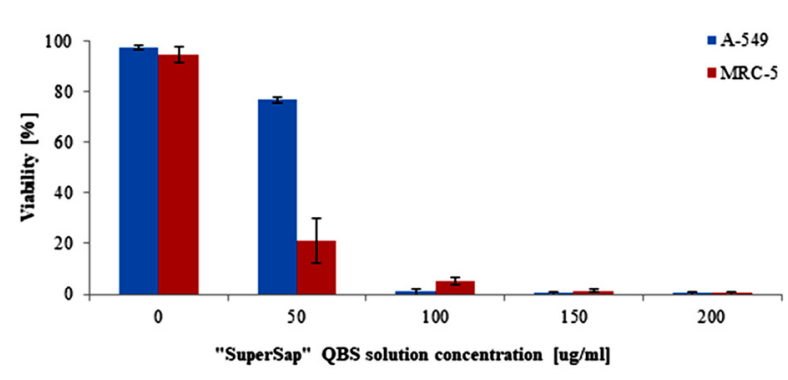

(b)

Figure 5. Viability of A-549 and MRC-5 cells after 24 h of incubation with (a) "Sigma" and (b) "SuperSap" QBS solution in the microfluidic device. The error bars were calculated as standard deviation from 12 and 8 independent experiments for A-549 and MRC-5 cells, respectively. 


\section{Discussion}

Comparing the macro- and the microscale results, we observed a very similar toxic effect of "SuperSap" QBS, with the exception of the lowest saponin concentration $(50 \mu \mathrm{g} / \mathrm{mL})$, where the A549 viability was significantly higher in the microscale. In the case of "Sigma" QBS, the results obtained with the MTT assay and microfluidic setup also showed a similar pattern, although the viability was systematically higher for the MRC-5 line in the macroscale. In the microfluidic setup, the complete cytotoxic effect of "Sigma" QBS could only be achieved at the highest saponin concentration. The differences in cytotoxicity between the two QBS mixtures were reproducible in both experimental setups and for both cell lines were clearly related to their composition. Interestingly, the higher biological activity of "SuperSap" (yet lower than typically observed for steroidal saponins, e.g., digitonin [24]) was previously observed also in hemolytic tests [16]. In the same contribution, we showed that the two mixtures differed significantly in their total saponin content, with "SuperSap" containing 20\% more saponins than "Sigma" (see Figure S1 in Supplementary Data and [16]). The generally higher cytotoxicity of "SuperSap" might thus at least partially be explained by its higher saponin content. On the other hand, the natural consequence of the lower saponin content of "Sigma" is the increased amount of a non-saponin fraction. In the HPLC chromatogram, it accounted for $17.4 \%$ of the total peak area (vs. only $2.7 \%$ in "SuperSap", see Figure S1 in Supplementary Data and [16]). This fraction is probably rich in hydrophilic tannins and phenolic compounds, such as (+)-piscidic acid, p-coumaric acid, glucosyringic acid, and vanillic acid, to name just a few found by Maier et al. in commercially available QBS mixtures [63]. It might be speculated that the non-saponin fraction of "Sigma" protects both types of cells against the membranolytic activity of the saponin fraction, further weakening cytotoxicity of the mixture. It is commonly known that polyphenols may serve as protective agents against various toxins and pollutants, even though their mechanism of action is still not clear. Plant polyphenols may also take part in communication between cells and are speculated to play a crucial role in anticarcinogenic, vascular, and cardioprotective activities $[64,65]$. The third major difference between "Sigma" and "SuperSap" that might significantly affect their cytotoxicity is the saponin profile. The analysis of large sets of data on biological activity of triterpenoid saponin shows that there is no single factor determining their toxicity towards the cells [66-68]. The data on biological activities of individual saponins is still very scarce and fragmentary. Nevertheless, among the few identified saponins present in QBS (Figure S2), there are some with high (e.g., QS-17 and QS-18) and some with low (e.g., QS-7 and QS-21) hemolytic activity [13]. The fact that the HPLC peaks corresponding to QS-17 and QS-18 were indeed the highest for "SuperSap", and those corresponding to QS-7 were the highest for "Sigma", correlates well not only with the higher hemolytic activity of "SuperSap", but also with its higher cytotoxicity described above.

To the best of our knowledge, the only data comparing cytotoxicity of saponins towards the tumor A-549 and normal MRC-5 lung cells concerns steroidal saponins from Dioscorea birmanica [69]. Our present results concerning triterpenoid saponins generally agree with the available literature data on a generally low cytotoxicity of QBS. The higher toxicity against the MRC- 5 cells reaffirms the expected poor applicability of both QBS mixtures in fighting lung cancer but, more importantly, confirms the key role of cholesterol in determining their biological activity.

Cholesterol plays a key role in plasma membranes [70], and there is an on-going debate concerning its role in cancer development. Consequently, the contradicting opinions exist on whether the differences in cholesterol content could be eventually employed for any diagnostic or therapeutic purposes. Although the tumor cells are generally known to have more fluid plasma membranes than the normal ones [71], there is no general consensus as to whether they indeed contain more or less cholesterol than their normal counterparts [72]. For example, prostate cancer is clearly linked to an enhanced cholesterol level in the prostate epithelial cells and in blood [73]. On the other hand, the opposite examples can be easily found in the literature. One such example are leukemic cells in 
mice and humans, where the unesterified cholesterol levels are lower than in the normal leukocytes [74]. Although in this study only the whole-cell lysates were assessed for the total cholesterol content, both spectrophotometric and fluorimetric analysis clearly point to about twice higher cholesterol content in the normal MRC-5 cells than in A-549. The cytotoxicity tests showed that high-cholesterol cells (MRC-5) are indeed more susceptible to the toxic effect of QBS than their low-cholesterol counterparts, both in the macroscopic and microscopic setups. In view of the generally accepted crucial role of cholesterol in saponins' affinity to biological membranes, the present cytotoxicity results could be easily explained by the differences in cholesterol content of both investigated lung cell lines. Whether this relation holds also for other cells with low and high cholesterol content remains an open question. Furthermore, the distribution of cholesterol molecules within the cell probably plays even more important role than its total content.

\section{Conclusions}

The total cholesterol content in the normal lung cell lines (MRC-5) is about twice higher than that in the tumor (A-549) line. The cytotoxicity of two commercially available Quillaja saponin mixtures (QBS) was found to correlate well with the total cholesterol level found in the normal (high cholesterol, high cytotoxicity) and tumor (low cholesterol, low cytotoxicity) lung cell lines. Although both mixtures showed higher cytotoxicity toward the MRC-5 line, the QBS mixture that had previously been shown to be more abundant in the saponin fraction and more hemolytic ("SuperSap") also showed higher cytotoxicity than "Sigma". The latter is enriched in the non-saponin fraction of tannins and phenolic compounds, which, combined with a specific saponin profile, is probably responsible for the observed lower cytotoxicity of "Sigma". The results were confirmed in both macro- and microscopic setups using the metabolic assay (MTT) and cell staining tests, respectively. Although in the present set of cell lines, the tumor cell line (A-549) was less abundant in cholesterol, which rendered it more resistant to QBS, many other cancer cells display elevated cholesterol levels. In such cases, QBS or other saponin mixtures may lead to enhanced cytotoxicity towards the unwanted tumor cells and could hopefully be employed as anticancer agents. This hypothesis requires experimental validation with more cell lines of known cholesterol content. The present observations may also help to explain why in some studies saponins prove effective against cancer cells, while in others this is not the case-their efficacy might in fact strongly depend on the actual cholesterol content in the given line, be it normal or tumor.

The microfluidic setup described in this contribution might serve in the future as a platform enabling for comparison of cytotoxicity of QBS and other potential anticancer drug candidates towards normal and cancerous cell lines. The main advantage of the setup is the minimization of the amount of sample required for single analysis, which might be especially useful for testing of individual components obtained by expensive purification procedures from the crude mixtures, e.g., of plant extracts.

Supplementary Materials: The following are available online at https: / www.mdpi.com/article / 10.3390/biophysica1020010/s1: Figure S1: RP-HPLC chromatograms of QBS mixtures (a) "Sigma", (b) "SuperSap". UV-VIS absorbance detection at $210 \mathrm{~nm}$ and the resulting relative content of major identified saponins in "Sigma" and "SuperSap" QBS extracts. Figure S2: Structures of identified saponins present in "Sigma" and "SuperSap".

Author Contributions: Conceptualization, M.C. and K.W.; methodology, M.C. and K.T.; investigation, N.K.; resources, M.C.; writing-original draft preparation, N.K.; writing-review and editing, K.W. All authors have read and agreed to the published version of the manuscript.

Funding: This research was funded by the Warsaw University of Technology.

Data Availability Statement: Not applicable.

Acknowledgments: Rodrigo Otero is kindly acknowledged for donation of "SuperSap" QBS.

Conflicts of Interest: The authors declare no conflict of interest. 


\section{References}

1. Francis, G.; Kerem, Z.; Makkar, H.P.S.; Becker, K. The biological action of saponins in animal systems: A review. Br. J. Nutr. 2002, 88, 587. [CrossRef] [PubMed]

2. Szakiel, A.; Paczkowski, C.; Henry, M. Influence of environmental biotic factors on the content of saponins in plants. Phytochem. Rev. 2011, 10, 493-502. [CrossRef]

3. Gus-Mayer, S.; Brunner, H.; Schneider-Poetsch, H.A.W.; Ruediger, W. Avenacosidase from oat: Purification, sequence analysis and biochemical characterization of a new member of the BGA family of b-glucosidases. Plant Mol. Biol. 1994, 26, 909-921. [CrossRef] [PubMed]

4. Weng, A.; Manunta, M.D.I.; Thakur, M.; Gilabert-Oriol, R.; Tagalakis, A.D.; Eddaoudi, A.; Munye, M.M.; Vink, C.A.; Wiesner, B.; Eichhorst, J.; et al. Improved intracellular delivery of peptide- and lipid-nanoplexes by natural glycosides. J. Control. Release 2015, 206, 75-90. [CrossRef] [PubMed]

5. Fuchs, H.; Weng, A.; Gilabert-Oriol, R. Augmenting the efficacy of immunotoxins and other targeted protein toxins by endosomal escape enhancers. Toxins 2016, 8, 200. [CrossRef]

6. Böttger, S.; Hofmann, K.; Melzig, M.F. Saponins can perturb biologic membranes and reduce the surface tension of aqueous solutions: A correlation? Bioorg. Med. Chem. 2012, 20, 2822-2828. [CrossRef] [PubMed]

7. Wojciechowski, K.; Piotrowski, M.; Popielarz, W.; Sosnowski, T.R. Short- and mid-term adsorption behaviour of Quillaja Bark Saponin and its mixtures with lysozyme. Food Hydrocoll. 2011, 25. [CrossRef]

8. Mitra, S.; Dungan, S.R. Micellar Properties of Quillaja Saponin. 1. Effects of Temperature, Salt, and pH on Solution Properties. J. Agric. Food Chem. 1997. [CrossRef]

9. Copaja, S.V.; Blackburn, C.; Carmona, R. Variation of saponin contents in Quillaja saponica molina. Wood Sci. Technol. 2003, 37, 103-108. [CrossRef]

10. Martín, R.S.; Briones, R. Industrial Uses and Sustainable Supply of Quillaja saponaria (Rosaceae) Saponins. Econ. Bot. 1999, 53, 302-311. [CrossRef]

11. Güçlü-Üstündağ, Ö.; Mazza, G. Saponins: Properties, Applications and Processing. Crit. Rev. Food Sci. Nutr. 2007, 47, 231-258. [CrossRef] [PubMed]

12. San Martin, R.; Briones, R. Quality control of commercial quillaja (Quillaja saponaria Molina) extracts by reverse phase HPLC. J. Sci. Food Agric. 2000, 80, 2063-2068. [CrossRef]

13. Ragupathi, G.; Gardner, J.R.; Livingston, P.O.; Gin, D.Y. Natural and synthetic saponin adjuvant QS-21 for vaccines against cancer. Expert Rev. Vaccines 2011, 10, 463-470. [CrossRef] [PubMed]

14. Wojciechowski, K.; Orczyk, M.; Gutberlet, T.; Trapp, M.; Marcinkowski, K.; Kobiela, T.; Geue, T. Unusual penetration of phospholipid mono- and bilayers by Quillaja bark saponin biosurfactant. Biochim. Biophys. Acta Biomembr. 2014, 1838. [CrossRef]

15. Pagureva, N.; Tcholakova, S.; Golemanov, K.; Denkov, N.; Pelan, E.; Stoyanov, S.D. Surface properties of adsorption layers formed from triterpenoid and steroid saponins. Colloids Surf. A Physicochem. Eng. Asp. 2016, 491, 18-28. [CrossRef]

16. Orczyk, M.; Wojciechowski, K. Comparison of the effect of two Quillaja bark saponin extracts on DPPC and DPPC/cholesterol Langmuir monolayers. Colloids Surf. B Biointerfaces 2015, 136, 291-299. [CrossRef]

17. Ransom, F. Saponin und sein Gegengift. Dtsch. Med. Wochenschr. 1901, 27, 194-196. [CrossRef]

18. Windaus, A. Über die Entgiftung der Saponine durch Cholesterin. Ber. Dtsch. Chem. Ges. 1909, 42, 238-246. [CrossRef]

19. Sidhu, G.S.; Oakenfull, D.G. A mechanism for the hypocholesterolaemic activity of saponins. Br. J. Nutr. 1986, 55, 643-649. [CrossRef]

20. Smith, W.S.; Baker, E.J.; Holmes, S.E.; Koster, G.; Hunt, A.N.; Johnston, D.A.; Flavell, S.U.; Flavell, D.J. Membrane cholesterol is essential for triterpenoid saponin augmentation of a saporin-based immunotoxin directed against CD19 on human lymphoma cells. Biochim. Biophys. Acta Biomembr. 2017, 1859, 993-1007. [CrossRef] [PubMed]

21. Singh, B.; Singh, J.P.; Singh, N.; Kaur, A. Saponins in pulses and their health promoting activities: A review. Food Chem. 2017, 233, 540-549. [CrossRef] [PubMed]

22. Korchowiec, B.; Janikowska-Sagan, M.; Kwiecińska, K.; Stachowicz-Kuśnierz, A.; Korchowiec, J. The role of cholesterol in membrane activity of digitonin: Experimental and theoretical model studies. J. Mol. Liq. 2021, 323. [CrossRef]

23. Malabed, R.; Hanashima, S.; Murata, M.; Sakurai, K. Interactions of OSW-1 with Lipid Bilayers in Comparison with Digitonin and Soyasaponin. Langmuir 2020, 36, 3600-3610. [CrossRef]

24. Orczyk, M.; Wojciechowski, K.; Brezesinski, G. The influence of steroidal and triterpenoid saponins on monolayer models of the outer leaflets of human erythrocytes, E. coli and S. cerevisiae cell membranes. J. Colloid Interface Sci. 2020, 563, 207-217. [CrossRef] [PubMed]

25. Geisler, R.; Dargel, C.; Hellweg, T. The biosurfactant $\beta$-aescin: A review on the physico-chemical properties and its interaction with lipid model membranes and langmuir monolayers. Molecules 2020, 25, 117. [CrossRef]

26. Verstraeten, S.L.; Deleu, M.; Janikowska-Sagan, M.; Claereboudt, E.J.S.; Lins, L.; Tyteca, D.; Mingeot-Leclercq, M.-P. The activity of the saponin ginsenoside Rh2 is enhanced by the interaction with membrane sphingomyelin but depressed by cholesterol. Sci. Rep. 2019, 9. [CrossRef]

27. De Groot, C.; Müsken, M.; Müller-Goymann, C.C. The bidesmosidic triterpene saponins hederacoside C and ginsenoside Rb1 exhibit low affinity to cholesterol in liposomal membranes. J. Drug Deliv. Sci. Technol. 2019, 53. [CrossRef] 
28. Goodman, J.R.; Jarnagin, L.P.; Meier, R.M.; Shonley, I.A. Determination of Free and Esterified Cholesterol by a Modified Digitonin-Anthrone Method. Anal. Chem. 1963, 35, 760-763. [CrossRef]

29. Nishikawa, M.; Nojima, S.; Akiyama, T.; Sankawa, U.; Inoue, K. Interaction of digitonin and its analogs with membrane cholesterol. J. Biochem. 1984, 96, 1231-1239. [CrossRef]

30. Holmes, S.E.; Bachran, C.; Fuchs, H.; Weng, A.; Melzig, M.F.; Flavell, S.U.; Flavell, D.J. Triterpenoid saponin augmention of saporin-based immunotoxin cytotoxicity for human leukaemia and lymphoma cells is partially immunospecific and target molecule dependent. Immunopharmacol. Immunotoxicol. 2015, 37, 42-55. [CrossRef]

31. Tatia, R.; Zalaru, C.; Tarcomnicu, I.; Moldovan, L.; Craciunescu, O.; Calinescu, I. Isolation and characterization of hederagenin from hedera helix L. Extract with antitumor activity. Rev. Chim. 2019, 70, 1157-1161. [CrossRef]

32. Jaramillo-Carmona, S.; Guillén-Bejarano, R.; Jiménez-Araujo, A.; Rodríguez-Arcos, R.; López, S. In Vitro Toxicity of Asparagus Saponins in Distinct Multidrug-Resistant Colon Cancer Cells. Chem. Biodivers. 2018, 15. [CrossRef] [PubMed]

33. Dutt, R.; Garg, V.; Khatri, N.; Madan, A.K. Phytochemicals in anticancer drug development. Anticancer Agents Med. Chem. 2019, 19, 172-183. [CrossRef]

34. Dahibhate, N.L.; Saddhe, A.A.; Kumar, K. Mangrove plants as a source of bioactive compounds: A review. Nat. Prod. J. 2019, 9, 86-97. [CrossRef]

35. Xu, J.; Wang, Z.; Huang, Y.; Wang, Y.; Xiang, L.; He, X. A spirostanol saponin isolated from Tupistra chinensis Baker simultaneously induces apoptosis and autophagy by regulating the JNK pathway in human gastric cancer cells. Steroids 2020, 164. [CrossRef]

36. Garrido, C.M.; Henkels, K.M.; Rehl, K.M.; Liang, H.; Zhou, Y.; Gutterman, J.U.; Cho, K.-J. Avicin G is a potent sphingomyelinase inhibitor and blocks oncogenic K- and H-Ras signaling. Sci. Rep. 2020, 10. [CrossRef]

37. Barr, A.M.; Silva, A.; Prato, S.; Belz, G.T.; Maraskovsky, E.; Baz Morelli, A. Therapeutic ISCOMATRIX ${ }^{\mathrm{TM}}$ adjuvant vaccine elicits effective anti-tumor immunity in the TRAMP-C1 mouse model of prostate cancer. Cancer Immunol. Immunother. 2020, 69, 1959-1972. [CrossRef]

38. Mbaveng, A.T.; Chi, G.F.; Nguenang, G.S.; Abdelfatah, S.; Tchangna Sop, R.V.; Ngadjui, B.T.; Kuete, V.; Efferth, T. Cytotoxicity of a naturally occuring spirostanol saponin, progenin III, towards a broad range of cancer cell lines by induction of apoptosis, autophagy and necroptosis. Chem. Biol. Interact. 2020, 326. [CrossRef]

39. Magedans, Y.V.S.; Yendo, A.C.A.; Costa, F.D.; Gosmann, G.; Fett-Neto, A.G. Foamy matters: An update on Quillaja saponins and their use as immunoadjuvants. Future Med. Chem. 2019, 11, 1485-1499. [CrossRef] [PubMed]

40. Podolak, I.; Galanty, A.; Sobolewska, D. Saponins as cytotoxic agents: A review. Phytochem. Rev. 2010, 9, 425-474. [CrossRef]

41. Roner, M.R.; Sprayberry, J.; Spinks, M.; Dhanji, S. Antiviral activity obtained from aqueous extracts of the Chilean soapbark tree (Quillaja saponaria Molina). J. Gen. Virol. 2007, 88, 275-285. [CrossRef] [PubMed]

42. Roner, M.R.; Tam, K.I.; Kiesling-Barrager, M. Prevention of rotavirus infections in vitro with aqueous extracts of Quillaja Saponaria Molina. Future Med. Chem. 2010, 2, 1083-1097. [CrossRef] [PubMed]

43. Arabski, M.; Weggierek-Ciuk, A.; Czerwonka, G.; Lankoff, A.; Kaca, W. Effects of saponins against clinical E. coli strains and eukaryotic cell line. J. Biomed. Biotechnol. 2012, 2012. [CrossRef]

44. Van De Ven, H.; Vermeersch, M.; Shunmugaperumal, T.; Vandervoort, J.; Maes, L.; Ludwig, A. Solid lipid nanoparticle (SLN) formulations as a potential tool for the reduction of cytotoxicity of saponins. Pharmazie 2009, 64, 172-176. [CrossRef] [PubMed]

45. Liu, Y.; Lu, H. Microfluidics in systems biology-hype or truly useful? Curr. Opin. Biotechnol. 2016, 39, 215-220. [CrossRef] [PubMed]

46. Tokarska, K.; Bazylinska, U.; Jastrzebska, E.; Chudy, M.; Dybko, A.; Wilk, K.A.; Brzozka, Z. Selective cancer-killing ability of new efficient porphyrin-based nanophotosensitizer in Lab-on-a-chip system. Sens. Actuators B Chem. 2019, 282, 665-674. [CrossRef]

47. Pandey, C.M.; Augustine, S.; Kumar, S.; Kumar, S.; Nara, S.; Srivastava, S.; Malhotra, B.D. Microfluidics Based Point-of-Care Diagnostics. Biotechnol. J. 2018, 13. [CrossRef]

48. Bruijns, B.; van Asten, A.; Tiggelaar, R.; Gardeniers, H. Microfluidic devices for forensic DNA analysis: A review. Biosensors 2016, 6, 41. [CrossRef]

49. Monošík, R.; Angnes, L. Utilisation of micro- and nanoscaled materials in microfluidic analytical devices. Microchem. J. 2015, 119, 159-168. [CrossRef]

50. Sousa, M.P.; Arab-Tehrany, E.; Cleymand, F.; Mano, J.F. Surface Micro- and Nanoengineering: Applications of Layer-by-Layer Technology as a Versatile Tool to Control Cellular Behavior. Small 2019, 15. [CrossRef]

51. Lee, S.; Kim, H.; Lee, W.; Kim, J. Microfluidic-based cell handling devices for biochemical applications. J. Micromech. Microeng. 2018, 28. [CrossRef]

52. Hu, C.; Chen, Y.; Tan, M.J.A.; Ren, K.; Wu, H. Microfluidic technologies for vasculature biomimicry. Analyst 2019, $144,4461-4471$. [CrossRef]

53. Wang, Z.; Kim, M.-C.; Marquez, M.; Thorsen, T. High-density microfluidic arrays for cell cytotoxicity analysis. Lab Chip 2007, 7, 740-745. [CrossRef] [PubMed]

54. Ziolkowska, K.; Jedrych, E.; Kwapiszewski, R.; Lopacinska, J.; Skolimowski, M.; Chudy, M. PDMS/glass microfluidic cell culture system for cytotoxicity tests and cells passage. Sens. Actuators B Chem. 2010, 145, 533-542. [CrossRef]

55. Wojciechowski, K.; Orczyk, M.; Gutberlet, T.; Geue, T. Complexation of phospholipids and cholesterol by triterpenic saponins in bulk and in monolayers. Biochim. Biophys. Acta Biomembr. 2016, 1858, 363-373. [CrossRef] 
56. Korchowiec, B.; Gorczyca, M.; Wojszko, K.; Janikowska, M.; Henry, M.; Rogalska, E. Impact of two different saponins on the organization of model lipid membranes. Biochim. Biophys. Acta Biomembr. 2015, 1848, 1963-1973. [CrossRef] [PubMed]

57. Glauert, A.M.; Dingle, J.T.; Lucy, J.A.; Bangham, A.D.; Horne, R.W. Action of Saponin on Biological Cell Membranes. Nature 1962, 196, 952-953. [CrossRef]

58. Augustin, J.M.; Kuzina, V.; Andersen, S.B.; Bak, S. Molecular activities, biosynthesis and evolution of triterpenoid saponins. Phytochemistry 2011, 72, 435-457. [CrossRef] [PubMed]

59. Lorent, J.; Le Duff, C.S.; Quetin-Leclercq, J.; Mingeot-Leclercq, M.-P. Induction of highly curved structures in relation to membrane permeabilization and budding by the triterpenoid saponins, $\alpha$ - And $\delta$-hederin. J. Biol. Chem. 2013, 288, 14000-14017. [CrossRef]

60. Armah, C.N.; Mackie, A.R.; Roy, C.; Price, K.; Osbourn, A.E.; Bowyer, P.; Ladha, S. The membrane-permeabilizing effect of avenacin A-1 involves the reorganization of bilayer cholesterol. Biophys. J. 1999, 76, 281-290. [CrossRef]

61. Keukens, E.A.J.; De Vrije, T.; Jansen, L.A.M.; De Boer, H.; Janssen, M.; De Kroon, A.I.P.M.; Jongen, W.M.F.; De Kruijff, B. Glycoalkaloids selectively permeabilize cholesterol containing biomembranes. Biochim. Biophys. Acta Biomembr. 1996, 1279, 243-250. [CrossRef]

62. Giard, D.J.; Aaronson, S.A.; Todaro, G.J.; Arnstein, P.; Kersey, J.H.; Dosik, H.; Parks, W.P. In vitro cultivation of human tumors: Establishment of cell lines derived from a series of solid tumors. J. Natl. Cancer Inst. 1973, 51, 1417-1423. [CrossRef] [PubMed]

63. Maier, C.; Conrad, J.; Carle, R.; Weiss, J.; Schweiggert, R.M. Phenolic constituents in commercial aqueous quillaja (Quillaja saponaria Molina) Wood extracts. J. Agric. Food Chem. 2015, 63, 1756-1762. [CrossRef] [PubMed]

64. Tarahovsky, Y.S. Plant polyphenols in cell-cell interaction and communication. Plant Signal. Behav. 2008, 3, 609-611. [CrossRef] [PubMed]

65. Grootaert, C.; Kamiloglu, S.; Capanoglu, E.; Van Camp, J. Cell systems to investigate the impact of polyphenols on cardiovascular health. Nutrients 2015, 7, 9229-9255. [CrossRef] [PubMed]

66. Chwalek, M.; Lalun, N.; Bobichon, H.; Plé, K.; Voutquenne-Nazabadioko, L. Structure-activity relationships of some hederagenin diglycosides: Haemolysis, cytotoxicity and apoptosis induction. Biochim. Biophys. Acta Gen. Subj. 2006, 1760, $1418-1427$. [CrossRef]

67. Gevrenova, R.; Weng, A.; Voutguenne-Nazabadioko, L.; Thakur, M.; Doytchinova, I. Quantitative Structure-Activity Relationship Study on Saponins as Cytotoxicity Enhancers. Lett. Drug Des. Discov. 2014, 12, 166-171. [CrossRef]

68. De Groot, C.; Müller-Goymann, C.C. Saponin Interactions with Model Membrane Systems-Langmuir Monolayer Studies, Hemolysis and Formation of ISCOMs. Planta Med. 2016, 82, 1496-1512. [CrossRef]

69. Jaiare, N.; Ithara, A.; Kumapav, K. Cytotoxic saponin against lung cancer cells from Dioscorea birmanica Prain \& Burkill. J. Med. Assoc. Thail. 2010, 93, 192-197.

70. Trapani, L.; Segatto, M.; Pallottini, V. Regulation and deregulation of cholesterol homeostasis: The liver as a metabolic "power station". World J. Hepatol. 2012, 4, 184-190. [CrossRef] [PubMed]

71. Inbar, M.; Goldman, R.; Inbar, L.; Bursuker, I.; Goldman, B.; Akstein, E.; Segal, P.; Ipp, E.; Ben-Bassat, I. Fluidity difference of membrane lipids in human normal and leukemic lymphocytes as controlled by serum components. Cancer Res. 1977, 37, 3037-3041.

72. Kuzu, O.F.; Noory, M.A.; Robertson, G.P. The role of cholesterol in cancer. Cancer Res. 2016, 76, 2063-2070. [CrossRef]

73. Krycer, J.R.; Brown, A.J. Cholesterol accumulation in prostate cancer: A classic observation from a modern perspective. Biochim. Biophys. Acta Rev. Cancer 2013, 1835, 219-229. [CrossRef]

74. Inbar, M.; Shinitzky, M. Cholesterol as a bioregulator in the development and inhibition of leukemia. Proc. Natl. Acad. Sci. USA 1974, 71, 4229-4231. [CrossRef] 